\title{
Variation of the quantitative traits in a progeny test of Abies alba (Mill.) at the nursery stage
}

\author{
By G. Minai ${ }^{1)}$, I. Mirancea ${ }^{1)}$ and C. Duta ${ }^{1)}$
}

(Received $28^{\text {th }}$ October 2014)

\begin{abstract}
Fifty-one full-sib families were created using 11 parents in a silver fir seed orchard and a half-diallel mating design. The seeds of control-pollinated families were sown in a nursery in autumn 2007. Growth and branches traits were measured during nursery testing, and genetic parameters were estimated at the ages of $3,4,5$, and 6 years. The additive and dominance genetic variances were major sources of genetic variance. Dominance variance was greater than additive variance at these early ages for all traits. However, the ratio of SCA/GCA variance decreased from 23 to 14 for total height and from 36 to 19 for root collar diameter. Broadsense family heritability is higher than individual heritability. Height and root collar diameter are the most heritable traits in silver fir. The time trend of the five heritability estimates for total height increased with age. Significant trait-trait genetic correlations were obtained. Age-age genetic correlations were very high, and they displayed increasing trends with age. The selection of the most valuable parents and most valuable individuals within the best families could maximise genetic gain in the second breeding generation of silver fir.
\end{abstract}

Key words: Additive variance, non-additive variance, genetic correlations, genetic gain, heritability, silver fir.

\section{Introduction}

The European silver fir (Abies alba Mill.) is an important forest species in Europe, both from economical and ecological points of view. In Romania, it covers $5 \%$ of the national forest area, which ranks second after the Norway spruce (Picea abies [L.] Karst). European silver fir occurs naturally in the mixed forest with Norway spruce and European beech and contributes mostly to increased stability of Norway spruce stands against wind. The restriction of its natural range is mainly due to human impact over time: deforestation, clear-cut treatment, and the use of Norway spruce in reforestation to the detriment of European silver fir and European beech. In recent years, due to widespread windfall occurring in pure spruce stands, the percent of European silver fir has increased in reforestations, mainly in mixed forests. Also, European silver fir is among species that occupy a substantial part in the forest sector; its timber is used for construction, furniture, plywood, and pulpwood. The silver fir annual mean increment is $9-13 \mathrm{~m}^{3} \cdot$ year $^{-1}$.

\footnotetext{
1) Forest Research and Management Institute (ICAS), Department of Forest Genetics and Tree Breeding, Eroilor 128, Voluntari, Romania. Tel.: +40213503245. E-Mail: genetica@icas.ro

*) Corresponding author: GEORGETA MiHAI.

E-Mail: gmihai_2008@yahoo.com
}

$\mathrm{ha}^{-1}$, according to the National Forest Inventory (1984).

The genetic variability observed in natural populations and provenance tests resulted in the decision to launch a European silver fir breeding programme in Romania in the 1980s (DAMIAN and LEANDRU, 1984; MiHAI et al., 2007; MiHAI, 2009). Establishing the firstgeneration seed orchards was one of the first steps in the Romanian breeding programme (ENESCU, 1972). During the years 1979-1984, 550 plus trees were selected from 15 provenance regions and were grafted in 11 seed orchards. They now fulfil several functions, including the following: 1) serve as the first-generation breeding population and provide a broad genetic base; 2) produce seed for operational reforestation; and 3) serve for making selections for second-generation seed orchards.

The development of an effective breeding programme for a given species depends primarily on the information about the inheritance patterns of its economically important characters, particularly the relative importance of additive, dominance, and epistatic genetic variances (Morgenstern, 1974). Additive effects of genes are the main source of genetic variation exploited by most breeding programmes. However, the interactions between alleles at a locus (dominance) and, particularly, the interactions of alleles between loci (epistasis) could play a central role in heterosis, polymorphism, and evolution. The levels of the additive and non-additive genetic variance in traits important for breeding programmes and the time trend of genetic parameters have a great impact on the determination of optimal breeding strategies.

Beginning in 2007, an advanced-generation breeding plan for European silver fir began in Romania (MIHAI, 2007). To evaluate the breeding value of plus trees from first-generation seed orchards and to produce progeny for field tests, a half-diallel mating design was used. Information on genetic parameters of the progenies will be used for future selection and breeding. These will complete the first breeding generation of silver fir in Romania and will be necessary to advance to the second breeding generation.

Although in the literature there are a number of studies reporting estimates of genetic parameters for forest species, very little is known about contribution of genetic variance components to growth or other traits in silver fir. Most results are based on provenance or progeny tests with open-pollinated material collected from trees growing in native stands (KORPEL et al., 1982; LARSEN and MeKic, 1991; Kranenborg, 1994; Wolf, 1994; MIHAI, 2009). Furthermore, so far there are no papers published on diallel crossing in European silver fir, despite its broad usage for other tree species such as 
Pseudotsuga menziesii (YEH and HEAMAN, 1987; Yanchuk, 1996; Dean and Stonecypher, 2006), Pinus radiata (WILCOX et al., 1975; CotTERILL et al., 1987; Matheson et al., 1994), Pinus taeda (Schmidtling and Nelson, 1996; XIANG et al., $2003 \mathrm{a}, \mathrm{b}$; Pinus sylvestris (Jonsson et al., 1998), and Picea abies (SkropPa, 1996).

In this paper, results from an $11 \times 11$ half-diallel experiment with silver fir at the nursery stage are presented. The objective is to provide early information about genetic variation and genetic parameters of some characters of silver fir. The results will be discussed in relation to their implications for future breeding activities.

\section{Materials and methods}

\section{Genetic material and mating design}

In the spring of 2007, 11 clones from a European silver fir seed orchard were mated in a half-diallel design, resulting in 51 full-sib families out of 55 possible crosses. Flowering of the seed orchard was very good during that year, and 1-2 ramets for each clone were involved in the diallel mating scheme. The seed orchard is situated in the Adancata Forest District and is composed of vegetative copies of 46 plus trees selected from five provenance regions. To maintain high genetic diversity in future generations, clones selected for crossing schemes come from all five provenance regions of plus trees. The flowers were isolated in paper bags on 20-21 April 2007, soon after the occurrence but prior to pollen dissemination. Pollination was made with fresh pollen on 27-28 April 2007.

\section{Nursery design and measurements}

Seeds of 51 full-sib families were sown in nursery beds for germination in autumn 2007. At the age of 2, the seedlings were planted in polyethylene bags filled with humus in a randomised complete block design. Each of the 51 families was represented by 10 seedlings per plot, replicated three times. Characters measured included the following: total height at the ages of $3,4,5$, and 6 (H3, H4, H5, H6) in centimetres; current height increment at ages 3,5 , and $6(\mathrm{~h} 3, \mathrm{~h} 5, \mathrm{~h} 6)$ in centimetres; root collar diameter at the ages of $3,4,5$, and 6 (DRC3, DRC4, DRC5, DRC6) in centimetres; branch length at the ages of 3 and 6 (LB3, LB6) in centimetres; and number of branches at the ages of 3 and 5 (NRB3, NRB5).

\section{Statistical analysis}

A half-diallel mating design was used (method 4; GRIFFING, 1956 a), taking into account only direct crossings; reciprocal crosses and self-pollination were excluded. All effects were considered random for estimation of variance components (model II, random; GRIFFING, $1956 \mathrm{~b}$ ), because the tested trees were random samples from the parent populations. Three parents had missing 1-2 crosses, for a total of four missing crossings in the whole experiment. However, according to WU and MATHESON (2000, 2001) and JoHnson and KING (1998), missing a few crosses, relative to the complete half-diallel design, will not significantly alter the hypothesis testing for the effects of replication, general combining ability effect (GCA), and specific combining ability effect (SCA), and it will not significantly affect the relative GCA ranking of parents.

The statistical analysis used individual seedling measurements and followed the mathematical model:

$$
\mathrm{X}_{\mathrm{ijk}}=\mu+\mathrm{r}_{\mathrm{k}}+\mathrm{g}_{\mathrm{i}}+\mathrm{g}_{\mathrm{j}}+\mathrm{s}_{\mathrm{ij}}+\mathrm{e}_{\mathrm{ijk}}
$$

where:

$\mathrm{X}_{\mathrm{ijk}}=$ the individual seedling observation

$\mu=$ the overall mean

$\mathrm{r}_{\mathrm{k}}=$ the effect of the $\mathrm{k}^{\text {th }}$ repetition

$\mathrm{g}_{\mathrm{i}}=$ the general combining ability effect (GCA) of the $\mathrm{i}^{\text {th }}$ parent

$g_{j}=$ the general combining ability effect (GCA) of the $\mathrm{j}^{\text {th }}$ parent

$s_{i j}=$ the specific combining ability effect (SCA) of the $\mathrm{i}^{\text {th }}$ and $\mathrm{j}^{\text {th }}$ parents so that $\mathrm{s}_{\mathrm{ij}}=\mathrm{s}_{\mathrm{ji}}$

$\mathrm{e}_{\mathrm{ijk}}=$ the random error associated with $\mathrm{ijk}{ }^{\text {th }}$ seedling

The model of variance analysis and expected mean squares are listed in Table 1. The analyses were based on plot means using the least-squares method by SCHAFFER and USANIS (1969). Because data on individual seedlings were available, a separate analysis was performed to estimate the within-plot variance $\left(\sigma_{\mathrm{w}}^{2}\right)$ (KRIEBEL et al., 1972; KRIEBEL et al., 1974; NAMKOONG and RoBERTs, 1974).

Table 1. - Analysis of variance of the half-diallel and expected mean squares (GRIFFING, 1956a).

\begin{tabular}{|c|c|c|c|c|}
\hline Source & Df & MS & $\mathrm{E}(\mathrm{MS})^{\prime}$ & F I'est \\
\hline Repetition & $r-1$ & $\mathrm{MS}_{\mathrm{Rep}}$ & $\begin{array}{l}\sigma^{2}{ }_{w}+{ }^{+} \mathrm{n}[\mathrm{p}(\mathrm{p}- \\
1) / 2] \sigma^{2}{ }_{\mathrm{R}}\end{array}$ & $\mathrm{MS}_{\mathrm{Rep}} / \mathrm{MS}_{\mathrm{L}}$ \\
\hline GCA & $p-1$ & $M S_{C C A}$ & $\begin{array}{l}\sigma_{w}^{3}+n r \sigma_{s C A}^{2}+\operatorname{nr}(p \\
-2) \sigma_{(\alpha C A}^{2}\end{array}$ & $\mathrm{MS}_{\mathrm{CCA}} / \mathrm{MS}_{\mathrm{SCA}}$ \\
\hline $\begin{array}{l}\text { SCA } \\
\text { Error }\end{array}$ & $\begin{array}{l}\mathrm{p}(\mathrm{p}-3) / 2 \\
(\mathrm{r}-1)\left\{\left[\left(\mathrm{p}^{?}-\mathrm{p}\right) / 2\right]-\right. \\
1\}\end{array}$ & $\begin{array}{l}M S_{S C A} \\
M S_{F}\end{array}$ & $\begin{array}{l}\sigma_{\mathrm{w}}^{2}+\mathrm{nr}^{2} \mathrm{SCA}^{2} \\
\sigma_{\mathrm{e}}^{2}=\sigma_{\mathrm{p}}^{2}+\sigma_{\mathrm{w}}^{2} / \mathrm{n}\end{array}$ & $\mathrm{MS}_{\mathrm{SC}} / \mathrm{MS}_{\mathrm{I}}$ \\
\hline $\begin{array}{l}\text { Within-plot } \\
\text { crror }\end{array}$ & $\mathbf{r}[\mathrm{p}(\mathrm{p}-1) / 2](\mathrm{n}-1)$ & $\mathrm{MS}_{W}$ & $\sigma_{x}^{2}$ & \\
\hline
\end{tabular}

${ }^{1}$ Where $\sigma_{\mathrm{p}}^{2}=$ variance among plots, $\sigma_{\mathrm{w}}^{2}=$ variance among full-sib within-plots, $\sigma_{\mathrm{p}}^{2}=\sigma_{\mathrm{e}}^{2}-$ $\sigma_{\mathrm{w}}^{2} / \mathrm{n}, \sigma_{\mathrm{GCA}}^{2}=\left(\mathrm{MS}_{\mathrm{GCA}}-\mathrm{MS}_{\mathrm{SCA}}\right) /(\mathrm{p}-2), \sigma_{\mathrm{SCA}}^{2}=\mathrm{MS}_{\mathrm{SCA}}-\mathrm{MS}_{\mathrm{E}} ; \mathrm{p}=$ number of parents; $\mathrm{n}=$ number of seedlings per plot; $r=$ number of repetitions. 
The components of variance derived from the linear model were expressed in their genetic expectations according to BECKER (1967). It was assumed that epistatic components of genetic variance were negligible in the population examined. Progeny tests were established with seedling material, and, consequently, no estimate of epistasis is available. Estimates of additive and dominance variances for quantitative traits require the assumption that epistasis is absent (COCKERHAM, 1954). Therefore, general combining ability variance $\left(\sigma_{\mathrm{GCA}}^{2}\right)$ among all of the parents is used as an estimator of the additive genetic variance, and specific combining ability variance $\left(\sigma_{\mathrm{SCA}}^{2}\right)$ is an estimator of the dominance genetic variance:

$$
\begin{aligned}
\sigma^{2}{ }_{\mathrm{P}} & =\sigma_{\mathrm{G}}^{2}+\sigma_{\mathrm{e}}^{2} \\
\sigma^{2}{ }_{\mathrm{G}} & =2 \sigma_{\mathrm{GCA}}^{2}+\sigma_{\mathrm{SCA}}^{2} \\
\sigma^{2}{ }_{\mathrm{A}} & =4 \sigma^{2}{ }_{\mathrm{GCA}} \\
\sigma_{\mathrm{D}}^{2} & =4 \sigma_{\mathrm{SCA}}^{2}
\end{aligned}
$$

where:

$$
\begin{aligned}
\sigma^{2}{ }_{\mathrm{P}} & =\text { phenotypic variance, } \\
\sigma^{2}{ }_{\mathrm{G}} & =\text { genotypic variance } \\
\sigma^{2}{ }_{\mathrm{A}} & =\text { additive genetic variance, } \\
\sigma_{\mathrm{D}}^{2} & =\text { dominance genetic variance. }
\end{aligned}
$$

Standard errors (SE) of variance components were estimated according to BECKER's formulas (1967):

$$
\begin{aligned}
& \mathrm{SE}\left(\sigma_{\mathrm{GCA}}^{2}\right)= \sqrt{ }\left[2 /(\mathrm{p}-2)^{2}\right] *\left\{\left[\mathrm{MS}^{2}{ }_{\mathrm{GCA}} /(\mathrm{p}+1)\right]+\right. \\
&\left.\mathrm{MS}_{\mathrm{SCA}}^{2} /[2+\mathrm{p}(\mathrm{p}-3) / 2]\right\} \\
& \mathrm{SE}\left(\sigma^{2}{ }_{\mathrm{SCA}}\right)= \sqrt{ } 2 *\left\{\left\{\mathrm{MS}^{2}{ }_{\mathrm{SCA}} /[2+\mathrm{p}(\mathrm{p}-3) / 2]\right\}+\right. \\
&\left.\mathrm{MS}_{\mathrm{E}}{ }^{2} /\left(2+\mathrm{df}_{\mathrm{E}}\right)\right\} \\
& \mathrm{SE}\left(\sigma_{\mathrm{w}}^{2}{ }_{\mathrm{w}}\right)=\sqrt{ } 2 * \mathrm{MS}_{\mathrm{W}}{ }^{2} /\left(2+\mathrm{df}_{\mathrm{w}}\right)
\end{aligned}
$$

With appropriate respect to the different selection methods, the values of the heritability were calculated as follows (MUllin and PARK, 1992; XiANG et al., $2003 \mathrm{a}, \mathrm{b})$ :
Broad-sense full-sib family mean heritability:

$$
\begin{aligned}
\mathrm{H}_{\mathrm{FS}}^{2}= & \left(2 \sigma^{2}{ }_{\mathrm{GCA}}+\sigma^{2}{ }_{\mathrm{SCA}}\right) / \sigma^{2}{ }_{\mathrm{Ph} 1}=\left(2 \sigma^{2}{ }_{\mathrm{GCA}}+\sigma^{2}{ }_{\mathrm{SCA}}\right) / \\
& \left(2 \sigma^{2}{ }_{\mathrm{GCA}}+\sigma^{2}{ }_{\mathrm{SCA}}+\sigma^{2}{ }_{\mathrm{p}} / \mathrm{r}+\sigma_{\mathrm{w}}^{2} / \mathrm{rn}\right)
\end{aligned}
$$

and mass selection genetic gain when they are vegetatively propagated is:

$$
\Delta \mathrm{G}_{1}=\mathrm{H}_{\mathrm{FS}}^{2} \mathrm{i} \sigma_{\mathrm{Ph} 1}
$$

Narrow-sense full-sib family mean heritability:

$$
\begin{gathered}
\mathrm{h}_{\mathrm{FS}}^{2}=2 \sigma_{\mathrm{GCA}}^{2} / \sigma^{2}{ }_{\mathrm{Ph} 1}=2 \sigma_{\mathrm{GCA}}^{2} /\left(2 \sigma_{\mathrm{GCA}}^{2}+\sigma_{\mathrm{SCA}}^{2}+\right. \\
\left.\sigma_{\mathrm{p}}^{2} / \mathrm{r}+\sigma_{\mathrm{w}}^{2} / \mathrm{rn}\right)
\end{gathered}
$$

and genetic gain from full-sib family selection is:

$$
\Delta \mathrm{G}^{2}=\mathrm{h}_{\mathrm{FS}}^{2} \mathrm{i} \sigma_{\mathrm{Ph} 1}
$$

Narrow-sense half-sib family mean heritability:

$$
\begin{aligned}
\mathrm{h}^{2}{ }_{\mathrm{HS}}= & \sigma^{2}{ }_{\mathrm{GCA}} / \sigma^{2}{ }_{\mathrm{Ph} 2}=\sigma^{2}{ }_{\mathrm{GCA}} /\left[\mathrm{p} \sigma^{2}{ }_{\mathrm{GCA}} /(\mathrm{p}-1)+\right. \\
& \left.\sigma_{\mathrm{SCA}}^{2} /(\mathrm{p}-1)+\sigma_{\mathrm{p}}^{2} / \mathrm{r}(\mathrm{p}-1)+\sigma^{2}{ }_{\mathrm{w}} / \mathrm{rn}(\mathrm{p}-1)\right]
\end{aligned}
$$

\begin{tabular}{|c|c|c|c|c|c|c|c|}
\hline \multirow{2}{*}{$\begin{array}{l}\text { Griclic } \\
\text { parameters }\end{array}$} & & & \multicolumn{5}{|c|}{ Characlets } \\
\hline & 113 & 114 & 115 & 116 & h. 3 & 115 & $\mathrm{hn}$ \\
\hline$\sigma^{2} \cos \pm S A$ & $1,350(4) \pm 2,104$ & $-1.669(2) \pm 3.264$ & $4.354(3)+7.869$ & $19,742(7) \pm 21,322$ & $0,283(11) \pm 0,226$ & $1,290(9) \pm 1,160)$ & $5,399(1,3) \pm 3,907$ \\
\hline$\sigma_{\mathrm{SCn}}^{2} \pm \mathrm{SL}$ & $31.210(95) \pm 6.543$ & $75,502(97) \pm 15,786$ & $121,774(96) \pm 25,5,57$ & $2(69,645692) \pm 56,601$ & $2,260(88) \pm 0.479$ & $12,915(90) \pm 7.436$ & $34,920(85) \pm 7 .+26$ \\
\hline$\sigma_{E \pm}^{\prime} \pm \mathrm{SE}$ & $0.170 ! 1) \pm 0.024$ & $0.205(1) \pm 0.029$ & $0.695(1) \pm 0.097$ & $1.8033(1) \pm 0.252$ & $0.037(1) \pm 0.0015$ & $0.163(1) \pm 0.023$ & $0.692(2) \pm 0 .(1997$ \\
\hline$\sigma_{x: \pm S E}^{2}$ & $2.343 \pm 0.089$ & $3,2,32 \pm 0,123$ & $9.522 \pm 0.362$ & $15.216 \pm 0.580\}$ & $0.529 \pm 0.020$ & $1.997 \pm 0.076$ & $10.409 \pm 0.396$ \\
\hline$\sigma_{\text {lh }}^{2}$ & 32.730 & 77.384 & 126.824 & 291.191 & 2.581 & 14.367 & 41.011 \\
\hline$\sigma^{2} \operatorname{sen} / \sigma^{2} \omega$ & 23 & 45 & 28 & 14 & 8 & 10 & 6 \\
\hline
\end{tabular}

\begin{tabular}{|c|c|c|c|c|c|c|c|c|}
\hline \multirow{2}{*}{$\begin{array}{l}\text { Grathetic } \\
\text { palrameters }\end{array}$} & \multicolumn{8}{|c|}{ Charicters } \\
\hline & $\mathrm{DRC} 3$ & IRC4 & DRC5 & DRC6 & XRB3 & .NRB5 & LB3 & $\angle B 6$ \\
\hline$\sigma_{(\mathrm{CA} \pm S E}^{2}$ & $0.058(3) \pm 0.126$ & $0.293(4) \pm 0.432$ & $0.252(2) \pm 0.725$ & $1.053(5) \pm 1.398$ & $0.467(10) \pm 0.396$ & $0.044(4) \pm 0.072$ & $1.174(15) \pm 0.809$ & $3.388(9) \pm 3.099$ \\
\hline$\overline{\sigma^{2}}$ & $2.051,96) \pm 0.432$ & $6.257(95) \pm 0.021$ & $12.340(97) \pm 0.026$ & $19.509(94) \pm 0.087$ & $4.117(87) \pm 0.885$ & $1.090(94) \pm 0.274$ & $6.783(84) \pm 1.443$ & $34.899(90) \pm 7.383$ \\
\hline$\sigma_{\mathrm{F}}^{2} \pm S L$ & $0.020(1) \pm 0.003$ & $0.049(1) \pm 0.007$ & $0.05061) \pm 0.007$ & $0.146(1) \pm 0.020$ & $0.127(3) \pm 0.018$ & $0.020+2) \pm 0.0003$ & $0.136(2) \pm 0.019$ & $0.506(1) \pm 0.071$ \\
\hline$\overline{\sigma_{w}^{2}} \pm \mathrm{SE}$ & $0.191 \pm 0.0007$ & $0.562 \pm 0.021$ & $0.689 \pm 0.026$ & $2.281 \pm 0.087$ & $2.036 \pm 0.077$ & $0.458 \pm 0.017$ & $1.666 \pm 0.063$ & $7.235 \pm 0.275$ \\
\hline$\overline{\sigma_{\mu}^{2}}$ & 2.129 & 6600 & $126+3$ & 20.708 & 4.711 & 1.155 & $8 .(193$ & 38.792 \\
\hline$\sigma_{\mathrm{SA} A}^{2} / \sigma_{\mathrm{AXA}}^{2}$ & 36 & 21 & 49 & 19 & 9 & 25 & 6 & 10) \\
\hline
\end{tabular}

and genetic gain from half-sib family selection is:

$$
\Delta \mathrm{G}_{3}=\mathrm{h}^{2}{ }_{\mathrm{HS}} \mathrm{i} \sigma_{\mathrm{Ph} 2}
$$

Narrow-sense individual heritability:

$$
\begin{aligned}
& \mathrm{h}^{2}=4 \sigma^{2}{ }_{\mathrm{GCA}} / \sigma^{2}{ }_{\mathrm{Ph} 3}=4 \sigma_{\mathrm{GCA}}^{2} /\left(2 \sigma_{\mathrm{GCA}}^{2}+\sigma_{\mathrm{SCA}}^{2}+\right. \\
& \left.\sigma_{p}^{2}+\sigma_{w}^{2}\right)
\end{aligned}
$$

and genetic gain from selection among randomly placed seedlings in small test plantings was estimated by:

$$
\Delta \mathrm{G}_{4}=\mathrm{h}^{2} \mathrm{i} \sigma_{\mathrm{Ph} 3}
$$

If the parents of the best half-sib families will be mated, estimation of the genetic gain was obtained by doubling i:

$$
\Delta \mathrm{G}_{5}=2 \mathrm{~h}_{\mathrm{HS}}^{2} \mathrm{i} \sigma_{\mathrm{Ph} 2}
$$

The genetic gains were calculated both at the family and individual levels for the following different breeding strategies (NAMKOONG et al., 1966; FALCONER, 1981): individual or mass selection; individual selection for clonal deployment; backward selection on half-sib family; and forward selection on full-sib family mean based

Table 2. - Mean squares estimates from the analysis of variance of studied traits at different ages in the nursery test. 
Table 3. - Variance components, their standard errors and the ratio of dominance to additive variance for total height, annual height increment, root collar diameter, number of branches and branch length of full-sib families at different ages.

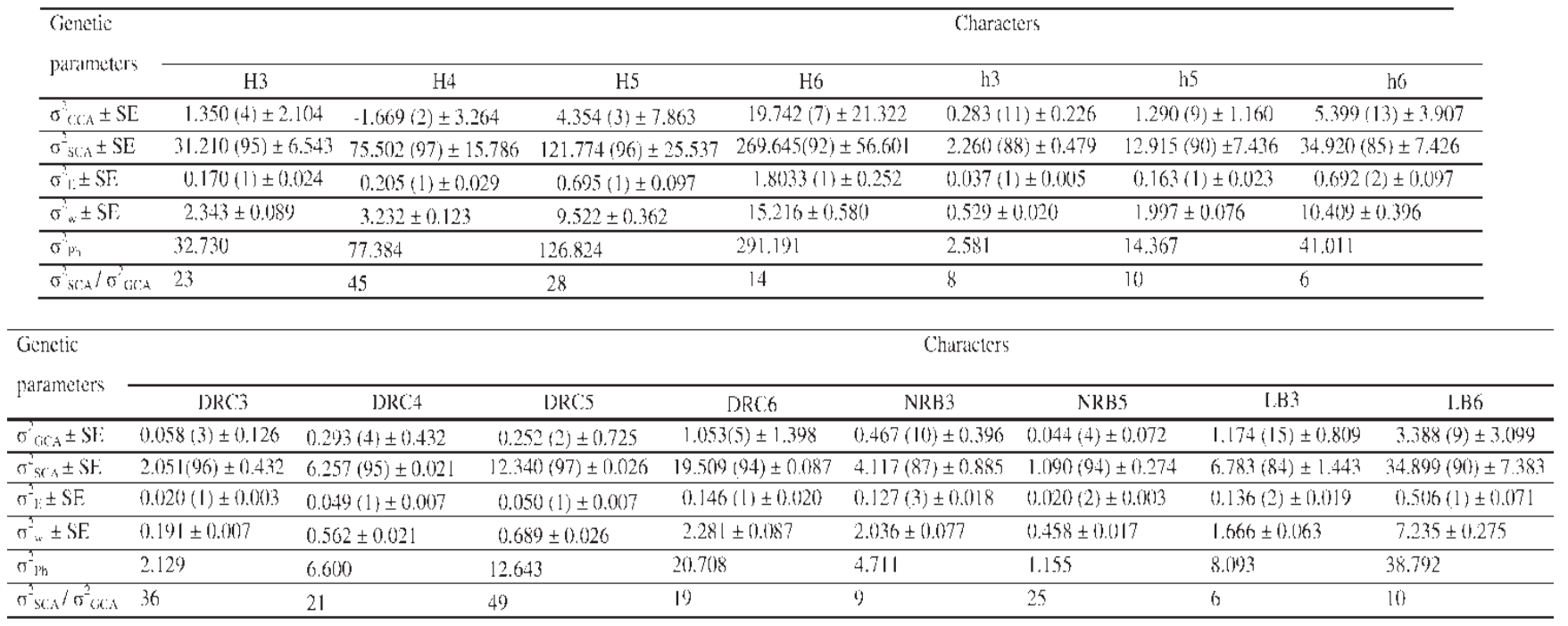

on additive or total genetic components. Selection intensity $i$ was 1.372 and 1.324 for full-sib and half-sib family selections (select top 20\%), respectively, and 1.354 for individual selection (select top 20\%).

General combining ability effects were estimated following methods of Griffing (1956 b). Differences between GCA effects were compared using the Student's "t-test".

Genetic correlations were calculated from the GCA covariance component of two characters in the numerator and the square root of the product of their GCA variance components in the denominator (XIANG et al., 2003a):

$$
\mathrm{r}_{\mathrm{Gxy}}=\sigma_{\mathrm{gxgy}} / \sqrt{ }\left(\sigma_{\mathrm{gx}}^{2} * \sigma_{\mathrm{gx}}^{2}\right)
$$

where: $\mathrm{X}, \mathrm{Y}$ are two traits, $\sigma_{\mathrm{gx}}^{2}$ or $\sigma_{\mathrm{gy}}^{2}$ is the GCA variance of traits $\mathrm{X}$ or $\mathrm{Y}$, respectively, and $\sigma_{\text {gxgy }}$ is the GCA covariance.

\section{Results}

\section{Genetic variation and variance components}

Analysis of variance of studied characters at different ages is presented in Table 2. The diallel analysis highlights significant $(\mathrm{p}<0.05)$ differences among parents regarding GCA for four traits and highly significant $(p<0.001)$ differences among families regarding SCA for all traits. Therefore, GCA effects are low at these early ages; on the contrary, SCA are very important sources of variation for the studied characters. This suggests that the traits of silver fir, including growth traits and habitus characters, appear to be mainly under non-additive gene actions (dominance), and only current height increment and branch characteristics were under additive gene actions, as well.
Variance component estimates, their standard errors, and dominance to additive ratios at ages $3,4,5$, and 6 are listed in Table 3. The results indicate that contribution of SCA variance $\left(\sigma^{2}{ }_{\mathrm{SCA}}\right)$ to the total phenotypic variance ranged from $97-92 \%$ for total height, $90-85 \%$ for current height increment, 97-94\% for root collar diameter, $94-87 \%$ for the number of branches, and $90-84 \%$ for branch length. Dominance variance $\left(\sigma^{2}{ }_{S C A}\right)$ exerted a greater influence at these years as evidenced by the $\sigma^{2}{ }_{\mathrm{SCA}} / \sigma_{\mathrm{GCA}}^{2}$ ratio. The values of the $\sigma_{\mathrm{SCA}}^{2} / \sigma_{\mathrm{GCA}}^{2}$ ratio ranged from $6-49$, depending on the analysed trait. The highest values were obtained for root collar diameter and total height.

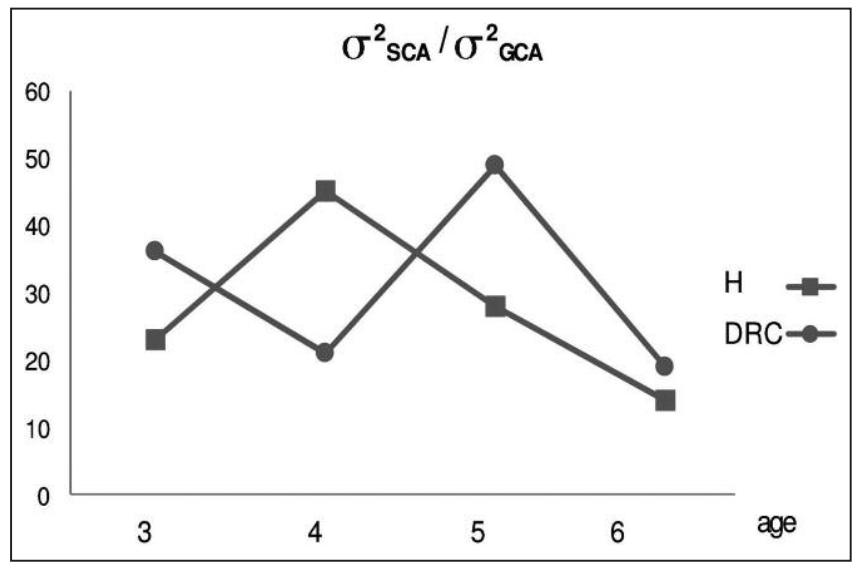

Figure 1. - Age trend of dominance ratios for total height $(\mathrm{H})$ and root collar diameter (DRC). 
The additive genetic variance for growth traits was small, but the general trend was to increase during the nursery stage (Fig. 1). Thus, $\sigma_{\text {GCA }}^{2}$ of the total height increased from $4 \%$ at age 3 to $7 \%$ at age 6 , and root collar diameter increased from $3 \%$ to $5 \%$ at the same age. Dominance genetic variance decreased over time from $95 \%$ to $92 \%$ for total height and from $96 \%$ to $94 \%$ for root collar diameter. Temporary variation of additive variance, which was observed for total height, and of root collar diameter is closely related to the variation of climatic parameters in those years. The years 2010 and 2012 were the warmest years in the analysed period and among the warmest years in the past decade, while 2011 was the driest year during the past 10 years (SANDU, 2013). Under the pressure of environmental factors, the additive genetic variation decreased, and non-additive gene action contributed to temporary response to selection. There are many examples that show a non-additive action of factors, such water, temperature, or nutrients, over the expression of traits (Holland, 2001; AROCA, 2012).

\section{Heritability}

The values of the heritability coefficients are listed in Table 4. As might be expected, narrow-sense heritability is very small because additive variance $\left(\sigma_{\mathrm{A}}^{2}\right)$ is very small at this stage. Narrow-sense individual heritability estimates ranged from 0.07 for DRC5 to 0.44 for LB3. The narrow-sense half-sib family heritability ranged from 0.21 for DRC3 to 0.59 for LB3, while narrow-sense full-sib family heritability was smaller, ranging from 0.04 for DRC5 to 0.26 for LB3. Broad-sense family heritability was 0.99 for all traits. In general, half-sib family heritability was higher than individual heritability and full-sib family heritability. Also, the heritability for overall $\mathrm{H}$ was much higher than those for overall DRC and NRB.

Slight increases were observed over time for narrowsense individual heritability and full-sib family heritability. In contrast, the half-sib family heritability varied considerably with time; between age 3 and 6 years, it increased by $72 \%$ for total height and by $63 \%$ for root collar diameter (Fig. 2). This variation of half-sib family heritability during those early years is due to additive genetic variation. The narrow-sense heritability includes only the additive genetic variance. It is well known that the environment influences the level of additive genetic variance, and, in particular, an increase in environmental stress may change the additive genetic variance and a decrease of the heritability in this case.

\section{General combining ability}

General combining ability effects were calculated for each parent (Table 5). Both positive and negative significant effects $(\mathrm{p}<0.001)$ were found for traits measured at the age of 6 years, with the exception of LB6. It is evident that parent 138 has the highest positive GCA effects for all the growth characters, while parents 5,376

Table 4. - Mean values and the estimates of phenotypic variances and heritabilities for examined traits.

\begin{tabular}{|c|c|c|c|c|c|c|c|c|c|}
\hline \multirow{2}{*}{$\begin{array}{l}\text { Genetic } \\
\text { parameters }\end{array}$} & \multicolumn{9}{|c|}{ Characters } \\
\hline & $\mathrm{H} 3$ & $\mathrm{H} 4$ & $\mathrm{H} 5$ & $\mathrm{H6}$ & $\mathrm{h} 3$ & & h5 & h6 & \\
\hline Mean & 10.655 & 13.986 & 18.123 & 25.039 & 2.652 & & 4.662 & 6.917 & \\
\hline$\sigma^{2}+$ H1 & 33.967 & 72.232 & 130.715 & 309.731 & 2.839 & & 15.548 & 45.948 & \\
\hline$\sigma^{2}+1,2$ & 4.612 & 5.721 & 16.991 & 48.741 & 0.539 & & 2.716 & 9.454 & \\
\hline$\sigma^{2}+t_{1.5}$ & 36.189 & 75.278 & 139.749 & 324.628 & 3.340 & & 17.454 & 55.778 & \\
\hline $\mathrm{H}^{2}$ & 0.998 & 0.999 & 0.998 & 0.998 & 0.996 & & 0.997 & 0.995 & \\
\hline $\mathrm{h}^{2}{ }_{1.4}$ & 0.293 & 0.292 & 0.256 & 0.405 & 0.525 & & 0.475 & 0.571 & \\
\hline $\mathrm{h}_{\mathrm{ES}}^{2}$ & 0.079 & 0.046 & 0.067 & 0.127 & 0.199 & & 0.166 & 0.235 & \\
\hline $\mathrm{h}^{2}$ & 0.149 & 0.089 & 0.125 & 0.243 & 0.339 & & 0.296 & 0.387 & \\
\hline \multicolumn{2}{|l|}{ Genctic } & \multicolumn{8}{|c|}{ Characters } \\
\hline parameters & $\mathrm{DRC} 3$ & DRC4 & DRCS & DRC6 & NRB3 & NRB5 & & LB3 & LB6 \\
\hline Mcan & 2.535 & 3.936 & 5.977 & 8.163 & 2.582 & 2.025 & & 3.679 & 9.606 \\
\hline$\sigma^{2}+111$ & 2.173 & 6.860 & 12.862 & 21.664 & 5.094 & 1.186 & & 9.176 & 41.842 \\
\hline$\sigma^{2}{ }_{p ! n}$ & 0.269 & 0.949 & 1.513 & 3.114 & 0.930 & 0.159 & & 1.974 & 7.233 \\
\hline$\sigma^{2}{ }^{2} 1,1,3$ & 2.359 & 7.398 & 13.515 & 23.815 & 7.011 & 1.611 & & 10.767 & 48.691 \\
\hline $\mathrm{H}^{2} \cdot .5$ & 0.997 & 0.998 & 0.999 & 0.998 & 0.992 & 0.994 & & 0.995 & 0.996 \\
\hline $\mathrm{h}^{3}{ }_{\mathrm{H} L S}$ & 0.214 & 0.308 & 0.167 & 0.338 & 0.503 & 0.280 & & 0.595 & 0.468 \\
\hline $\mathrm{h}^{2}, \mathrm{~s}$ & 0.053 & 0.085 & 0.039 & 0.097 & 0.184 & 0.075 & & 0.256 & 0.162 \\
\hline $\overrightarrow{h^{\prime}}$ & 0.098 & 0.158 & 0.075 & 0.177 & 0.267 & 0.110 & & 0.436 & 0.278 \\
\hline
\end{tabular}




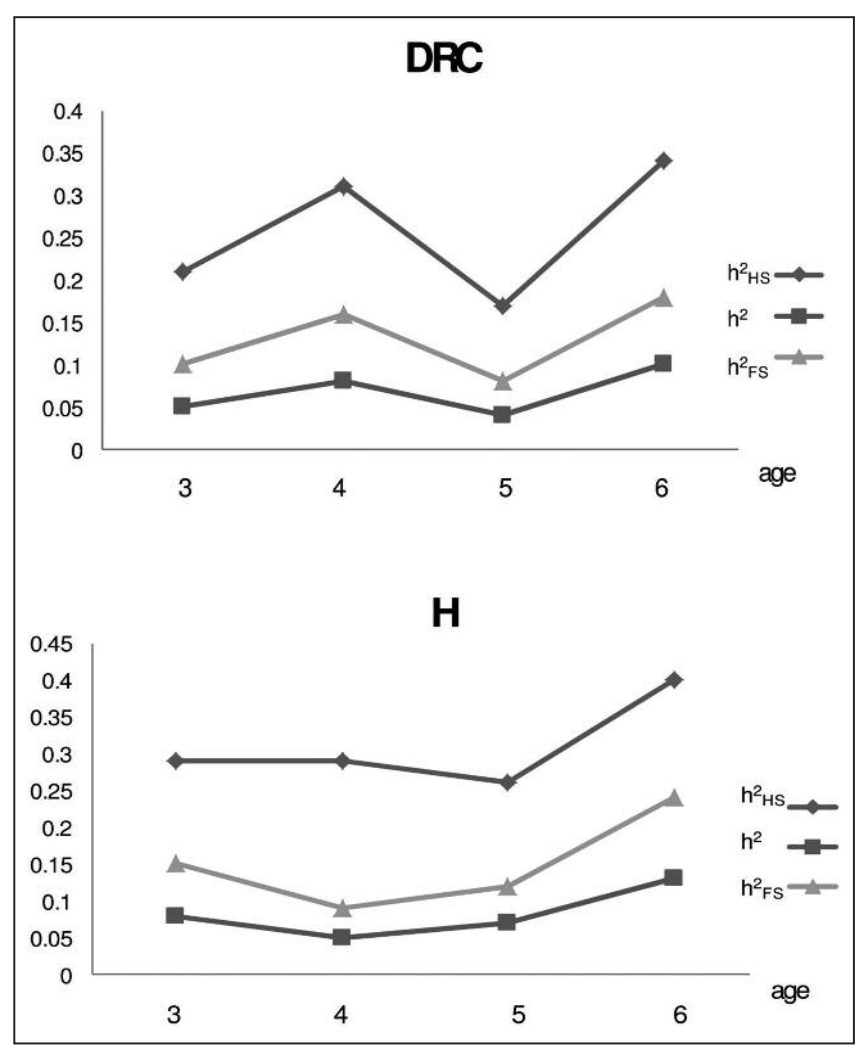

Figure 2. - Time trend of individual $\left(\mathrm{h}^{2}\right)$ and family heritabilities $\left(\mathrm{h}^{2}{ }_{\mathrm{HS}}, \mathrm{h}^{2}{ }_{\mathrm{FS}}\right)$ for total height $(\mathrm{H})$ and root collar diameter (DRC). and 421 show the most negative GCA effects. In a breeding programme, individuals with positive GCA values, situated above the experimental mean, are of interest. Therefore, the best parents in this experiment for growth characters at the age of 6 are clones 138, 134, 541, and 371, and the weakest parents are 5, 421, 376, and 145. The parents with moderate GCA effects are 35 and 544. Although, for DRC6, the parent trees exhibited approximately equal potential for generating crosses, for H6, the parents could be separated into three categories: very good combiners; moderate combiners; and parents that will be rejected from improvement programmes.

\section{Genetic correlations}

Age-age genetic correlations and genetic correlations between traits are shown in Table 6. High correlations were obtained for almost all traits at this very early growth stage. The genetic correlations between age 6 and the previous age for the total height increased over time. The total height correlations range from 0.44 at age 3 to 0.77 at age 6 . For current height increment and root collar diameter, correlations were less stable over time, likely due to the short time between ages $3-6$.

Very significant age-age correlations were obtained for $\mathrm{H}$, DRC, NRB, and LB. Only the current height increment displays one significant correlation between ages 5 and 6 . The additive age-age genetic correlations between DRC were much higher and stable than those for total height.

Table 5. - General combining ability effects for 11 parents in silver fir half-diallel.

\begin{tabular}{|c|c|c|c|c|c|c|c|c|}
\hline \multirow[t]{2}{*}{ Parent } & \multicolumn{7}{|c|}{ Characters } & \\
\hline & $\mathrm{H} 3$ & $\mathrm{H} 4$ & $\mathrm{H} 5$ & H6 & h3 & 115 & h6 & \\
\hline 5 & 0.936 & -1.280 & $-2,498$ & $-4.820^{k ; k}$ & 0.601 & -1.049 & $-2.322^{k-k \mid k=k}$ & \\
\hline 544 & 0.292 & 0.400 & 0.812 & 0.634 & 0.003 & 0.326 & -0.178 & \\
\hline 50 & -0.545 & 0.278 & -0.075 & -0.273 & -0.064 & 0.259 & -0.198 & \\
\hline 541 & 0.601 & 0.615 & 1.801 & $4.722 * * *$ & 0.323 & 1.565 & $2.921^{* * * * *}$ & \\
\hline 371 & 1.591 & 0.889 & 1,204 & $1.384 *$ & 0.197 & 0.116 & 0.181 & \\
\hline 35 & 0.509 & 0.497 & 0.560 & 0.112 & 0.030 & -0.288 & -0.448 & \\
\hline 138 & 1.159 & 2.489 & 3.851 & $5.940 \% * \%$ & 0.361 & 0.927 & $2.089 \% * * *$ & \\
\hline 376 & -1.653 & -1.963 & $-2,397$ & $-3.609^{\circ: 6}$ & -0.527 & -0.749 & $-1.211 \leqslant$ & \\
\hline 145 & -1.474 & -1.229 & -1.891 & $-2.991 * * *$ & -0.439 & -0.665 & $-1.100 \% *$ & \\
\hline 421 & -1.544 & -1.596 & -3.081 & $-4.355^{\prime *}$ & -0.578 & -1.123 & $-1.273^{\circ *}$ & \\
\hline 134 & 0.126 & 0.900 & 1.715 & $3.255^{t a b t}$ & 0.092 & 0.680 & $1.540^{;: k ; ; k}$ & \\
\hline \multirow[t]{2}{*}{ Parent } & \multicolumn{7}{|c|}{ Characters } & \\
\hline & DRC3 & DRC4 & DRC5 & DRC6 & & NRB5 & LB3 & LB6 \\
\hline 5 & -0.099 & -0.587 & -0.383 & $-0.5] 6 * * *$ & 0.194 & 0.400 & 0.205 & -0.658 \\
\hline 544 & -0.082 & 0.135 & 0.254 & 0.061 & 0.008 & 0.235 & -0.087 & 0.035 \\
\hline 50 & -0.171 & 0.074 & 0.06 .5 & $-0.309 \%$ & -0.284 & 0.025 & -0.266 & -0.357 \\
\hline 541 & 0.020 & -0.028 & 0.195 & $0.625 * \% *$ & 0.205 & -0.125 & 0.510 & 1.983 \\
\hline 371 & 0.365 & 0.310 & 0.480 & $0.930^{* * *}$ & 0.801 & 0.044 & 0.882 & 0.154 \\
\hline 35 & 0.233 & 0.209 & 0.511 & $0.676 * * *$ & 0.055 & 0.038 & 0.437 & -0.293 \\
\hline 138 & 0.403 & 0.848 & 0.944 & $1.399^{*} *$ & 0.412 & 0.138 & 0.775 & 2.369 \\
\hline 376 & -0.445 & -0.705 & -1.130 & $-1.417^{* * * *}$ & -0.652 & -0.255 & -0.989 & -1.782 \\
\hline 145 & -0.129 & -0.137 & -0.415 & $-0.624 * * *$ & -0.646 & -0.224 & -0.954 & -1.111 \\
\hline 421 & -0.332 & -0.742 & -1.027 & $-1.405^{* * *}$ & -0.644 & -0.288 & -1.055 & -1.764 \\
\hline 134 & 0.238 & 0.623 & 0.508 & $0.579 \% \%$ & 0.551 & 0.012 & 0.541 & 1.425 \\
\hline
\end{tabular}


Table 6. - Trait - trait and age - age additive genetic correlations.

\begin{tabular}{|c|c|c|c|c|c|c|c|c|c|c|c|c|c|c|c|}
\hline Trails & II 3 & II4 & H5 & 136 & h3 & 1.5 & h6 & DRC3 & DRC4 & LRC5 & DRC6 & ARB3 & NRB5 & LB3 & LB6 \\
\hline II.3 & - & $0.69^{\prime}$ & $0.65^{5 * 2}$ & $0.44^{*}: * *$ & $0.58^{* * *}$ & $0.35^{* *}$ & $0.27^{*}$ & $0.85^{* \neq * * *}$ & $0.52^{* * *}$ & $0.95 *$ & $0.69^{* * 1 *}$ & $0.61^{* * * *}$ & $0.71^{* * 1 * *}$ & $0.57^{* * * *}$ & $0.47^{* * \neq * 15}$ \\
\hline $3 \mathrm{I} 4$ & & - & $0.98^{1 * * 1}$ & $0.73^{* 1 *}$ & $0.41^{* * *}$ & $0.59^{1+2 * *}$ & 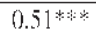 & $0.96^{* * * *}$ & $0.86^{* * *}$ & $0.82^{1: * 1 * 11}$ & $0.82^{2 * * 1 ;}$ & $0.53^{* 1 *}$ & $0.41^{* * 1}$ & $0.53=$ & $0.64: 1 *=$ \\
\hline II5 & & & - & $0.77^{*}$ & $0.39^{* * *}$ & $0.65^{* \infty}$ & $0.57^{* \% *}$ & $0.92^{* * *}$ & $0.85 \%$ & $0.81^{: t a t}$ & $0.82^{2+\%}$ & $0.52^{4 \% 8}$ & $0.33^{*}$ & 0.52 & $0.68 \%$ \\
\hline $\mathrm{H} 6$ & & & & $\begin{array}{lll}- & \\
\end{array}$ & $0.27^{*}$ & (1.54**** & $0.49+\%$ & $0.66 * \cdots$ & $0.62^{* * *}$ & $0.85 * *$ & $0.61 * 1 *$ & $0.37 * *$ & 0.14 & 0.38 科 & $0.54 * 1 *$ \\
\hline h.3 & & & & & & 0.24 & 0.17 & $0.49 \% * * *$ & $0.29 *$ & $0.58^{: * 1+\cdots}$ & $0.42 \%$ & $0.39 * *$ & $0.56^{1 \cdots * 2}$ & $0.37: 4$ & $0.35^{5 * * *}$ \\
\hline h5 & & & & & & - & $0.45^{4}$ & 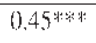 & 0.48 \% & 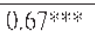 & $0.48 \%$ & $0,29^{*}$ & 0.10 & $0.30^{*}$ & $0.48 \%$ \\
\hline h6 6 & & & & & & & - & $0.43 * *$ & $0.43 * *$ & $0.56 * * *$ & $0,42^{* * *}$ & 0.25 & -0.02 & 0.26 & $0.44^{* *}$ \\
\hline $\mathrm{DSR} 3$ & & & & & & & & - & $0.89 * * *$ & $0.79 * * *$ & $0.92 * * * *$ & $0.67^{* * *}$ & $0.48 \% * \%$ & $0.64 * * *$ & 09.67 ***: \\
\hline DRCA & & & & & & & & & $\begin{array}{lll}- & \\
-1\end{array}$ & $0.89: 1:=$ & $0.72: 1: *$ & $0.45 \%$ & $0.31:=$ & 0.44 & $0.54: * ;$ \\
\hline DRC5 & & & & & & & & & & - & $0.79: 1:=$ & $0.71^{\text {: }: \text { : }}$ & $0.67^{\text {非 }}$ & 0.7 I:=1: & $0.77^{* 1 *: *}$ \\
\hline DRC6 & & & & & & & & & & & - & $0.52^{1 * 18}$ & $0.40^{\sharp 1 *}$ & 0.52 非非 & $0.56^{* 1 *: 1}$ \\
\hline NRB3 & & & & & & & & & & & & - & $0.42^{* *: 3}$ & $0.43 \%$ & $0.38: 1$ \\
\hline NRB5 & & & & & & & & & & & & & - & $0.39:=$ & 0.26 \\
\hline$L B 3$ & & & & & & & & & & & & & & - & $0.38^{* * *}$ \\
\hline
\end{tabular}

Table 7. - Expected genetic gain by selection of the best $20 \%$ families and individuals.

\begin{tabular}{lccccc}
\hline \multirow{2}{*}{ Character } & \multicolumn{3}{c}{ Family } & \multicolumn{3}{c}{ Individual } \\
\cline { 2 - 6 } & $\Delta \mathrm{G}_{1}$ & $\Delta \mathrm{G}_{1}$ & $\Delta \mathrm{G}_{3}$ & $\Delta \mathrm{G}_{4}$ & $\Delta \mathrm{G}_{5}$ \\
\hline $\mathrm{H6}$ & 96 & 13 & 15 & 24 & 25 \\
\hline DRC6 & 78 & 8 & 10 & 14 & 16 \\
\hline h6 & 134 & 32 & 34 & 57 & 57 \\
\hline NRB5 & 77 & 6 & 7 & 10 & 12 \\
\hline LB6 & 92 & 15 & 17 & 27 & 30 \\
\hline
\end{tabular}

With the exception of NRB at age 5, very significantly positive genetic correlations between DRC and the other traits were observed. Also, strong positive genetic correlations were obtained between total height and each trait. The fewest correlations were found between annual height increment and branch number.

However, these results need to be confirmed at an advanced age of the seedlings, when genetic parameters will be more stable.

\section{Genetic gain}

The genetic gain was calculated for the traits at age 6 as deviation (\%) from the population mean. Genetic gain ranged from 6-134\% and varied for different selection methods and analysed traits. Genetic gain that could be achieved at both family $\left(\Delta \mathrm{G}_{1}, \Delta \mathrm{G}_{2}, \Delta \mathrm{G}_{3}\right)$ and individual levels $\left(\Delta \mathrm{G}_{4}, \Delta \mathrm{G}_{5}\right)$ are presented in Table 7 .

Regardless of selection method, genetic gain is higher for annual height increment and total height than for root collar diameter. Also, large genetic gain is possible if indirect selection is performed on branch traits; there are very significant additive genetic correlations between them and growth traits. Regarding method of selection, family selection followed by vegetative multiplication $\left(\Delta \mathrm{G}_{1}\right)$ could achieve the greatest genetic gain in the breeding programme. However, the individual selection method, whether clonal deployment is used or not $\left(\Delta \mathrm{G}_{4}, \Delta \mathrm{G}_{5}\right)$, is greater than full-sib $\left(\Delta \mathrm{G}_{2}\right)$ or half-sib $\left(\Delta \mathrm{G}_{3}\right)$ family selection for all traits.

In this paper, individual selection refers to 1 ) the best parents, according to their GCA effects, and 2) selection among randomly placed seedlings in small test plantings. Genetic gains that could be expected by selecting and crossing the three best parents $\left(\Delta \mathrm{G}_{5}\right)$ are $25 \%$ in total height, $57 \%$ in current height increment, and $16 \%$ in root collar diameter. If the best $20 \%$ of individuals within full-sib families is selected $\left(\Delta \mathrm{G}_{4}\right)$, genetic gains of $24 \%$ for $\mathrm{H} 6$ and $14 \%$ for DRC6 could be achieved. Regarding the values of heritability and age-age and 
trait-trait genetic correlations, the maximum genetic gain that can be obtained at age 6 is achieved by applying individual selection for total height. Therefore, selection can be done at the parent level but also by selecting the best individuals within the best families. Selection of the best families combined with within-family selection has the advantage of capturing a non-additive genetic component already at an early age.

\section{Discussion}

Despite a broad use of the diallel mating design in forest species, there are no papers published on European silver fir. Most of these studies generally have shown that additive genetic variance was greater than dominance variance during early age with an increasing trend (Kriebel et al., 1974; Morgenstern, 1974; BARADAT and Desprez-Loustau, 1996; Xiang et al., 2003a). Results in our study indicated that non-additive variance had a greater influence on variation of studied traits compared to additive variance. Similar results were published by FrANKLIN (1979), Foster and BRIDGEWATER (1986), PAUL et al. (1997), and IsIK et al. (2003) for Pinus taeda, King et al. (1998) and Hodge et al. (1996) for Eucalyptus globulus, BLADA (1999) for Pinus cembra, and DeAn and StonecyPher (2006) for Douglas fir.

A large non-additive variance in growth and branches characters as determined in this experiment is in agreement with the genetic system of silver fir as a species with slow growth in early stages and a high degree of variation within populations (KONNERT and BERGMANN, 1995; HussendoRFER ,1999; LONGAUER et al., 2005; TEODosiu, 2009). The higher level of dominance variance observed in full-sib families indicates that culling families from the breeding population, based on poor performances, most likely will risk the loss of many potentially valuable genotypes. From a practical point of view, the age of 6 years represents the end of nursery growth, and these results have important practical implications regarding the initial selection of the seedlings at the juvenile stage.

However, the genetic additive variance generally increased over time. The $\sigma^{2}{ }_{\mathrm{SCA}} / \sigma^{2}{ }_{\mathrm{GCA}}$ ratio decreased from 23 to 14 for $\mathrm{H}$, from 8 to 6 for h, and from 36 to 19 for DRC. Also, narrow-sense family and individual heritability increased from age 2 to age 6 for all traits. At 6 years of age, the current height increment and total height are the most heritable traits in silver fir. The large values of heritability show that there is enough chance of success when using different selection methods in a breeding programme. For breeding programmes, it is important to assess trends over time of variance components, heritability estimates, and genetic correlations to optimise the timing of early selection and develop the most efficient strategy. Silver fir is a species with slow growth in first years and, as might be expected, selection pressure is greater at this early age. Certainly, reliable information only will be obtained after a longer testing period when genetic parameters stabilise.

In general, high genetic correlations were obtained in our study. Among analysed characters, the highest and stable additive age-age genetic correlations were for DRC.
Positive genetic correlations between DRC and $\mathrm{H}$ and the other traits were observed. Significant positive genetic correlations obtained between growth characters and branch characters suggest that genetic gain for growth traits could be obtained by indirect selection practised on easy measurable traits. Nevertheless, the stability of these correlations must be confirmed at older age.

For species improvement programmes, it is important to document strategies at key stages to set constraints and premises (WRIGHT, 1971; BURDON and van BUIJTENEN, 1990; White et al., 1993; Li and WYCKOFF, 1994; LI et al., 2001; KLein, 1998; DANUSEvicius and LindGREN, 2001; KANG et al., 2001). Knowledge of the genetic variation and heritability of the important characters will allow us to choose the most appropriate breeding strategies for silver fir. Diallel experiments revealed a large genetic variability at both the parent (GCA) and family levels (SCA), which can be used in a breeding programme.

Breeding could be possible by selecting the most valuable parents in terms of GCA effects and the most valuable individuals within the best families, according to their SCA. The high GCA would insure a high expected full-sib family mean when the parents are crossed, and the high SCA potential would provide the possibility to produce better-than-expected specific crosses. Comparison of the genetic gain calculated by different selection strategies indicates that backward selection, forward selection, and a combination of them can be used in breeding activities.

\section{Conclusions}

In spite of the young age of the tested material, several conclusions can be drawn from this study. There is very significant genetic variation in all traits at the fullsib progeny level. Non-additive genetic variance has a greater importance at this stage compared to additive genetic variance. Information on the GCA can be used to select the best parents from first-generation seed orchards. Selection can be done at the family and the individual within-family level as well as at the individual parent level. The estimated genetic gains suggest that selection is both economically and genetically justified. Age-age genetic correlations and correlations between age 6 and previous age of the same traits were very significant. The culling of seedlings from the breeding populations in the nursery stage based on poor performances should be avoided, since genetic effects at older age cannot be excluded. This information is important to develop a more efficient breeding strategy for the next silver fir breeding generation.

Consequently, first-generation seed orchards are not only a source of forest reproductive material but also of genetic material for the future seed orchards, even if they were not established primarily as a base for future selections.

\section{Acknowledgements}

The authors thank the National Forest Administration-Romsilva for financial support of the research pro- 
ject and the anonymous reviewers for their useful comments on earlier versions of this manuscript.

\section{Reference list}

ANONYMOUs (1984): National Forest Inventory, Statistical National Institute.

ArocA, R. (2012): Plant responses to drought stress: from morphological to molecular features. Springer Berlin Heidelberg, 466.

Baradat, P. and M. L. Deprez-Loustau (1996): Analyse diallele et integration de la sensibilite a la rouille courbeuse dans le programme d'amelioration du pin maritime. Ann Sci For 54, 83-106.

BECKER, W. A. (1967): Manual of procedures in quantitative genetics. Second edition, Academic Enterprise, Pullman, WA, 124-

BladA, I. (1999): Diallel crossing in Pinus cembra III. Analysis of genetic variation at the nursery stage. Silvae Genet 48, 3-4, 179-187.

BuRdon, R. D. and J. P. vAN BUIJTENEN (1990): Expected efficiencies of mating designs for reselection of parents. Can J For Res 20, 1664-1671.

Cockerham, C. C. (1954): An extension of the concept of partitioning hereditary variance for analysis of covariances among relatives when epistasis is present. Genetics 39, 859-882.

Cotterill, P. P., C. A. DEAN and G. VAN WyK (1987): Additive and dominance genetic effects in Pinus pinaster, P. radiata, and $P$. elliottii and some implications for breeding strategy. Silvae Genet 36, 221-232.

DAMIAN, M. and L. LEANDRU (1984): Culturi comparative de proveniente la brad. Redactia de propaganda tehnica agricola, Seria a II-a, 47.

DANusevicius, D. and D. LindGren (2001): Efficiency of selection based on phenotype, clone, and progeny testing in long-term breeding. Silvae Genet 51, 1, 19-26.

Dean, C. A. and R. W. Stonecypher (2006): Early selection of Douglas-fir across south-central coastal Oregon, USA. Silvae Genet 55, 3, 135-141.

ENEscu, V. (1972): Plantaje pentru producerea semintelor genetic ameliorate de specii valoroase si repede crescatoare. ICAS Seria II, 143.

FALCONER, D. S. (1981): Introduction to quantitative genetics. Longman and Co., New-York, NY, 340.

Foster, G. S. and F. E. BRIDGwater (1986): Genetic analysis of fifth-year data from a 17-parent partial diallel of loblolly pine. Silvae Genet 35, 2-3, 118-122.

FrANKLIN, E. C. (1979): Model relating levels of genetic variance to stand development of four North American conifers. Silvae Genet 28, 207-212.

GRIFFING, B. (1956a): A generalised treatment of the use of diallel crosses in quantitative inheritance, Heredity 10, 31-50.

GRIFFING, B. (1956b): Concept of general and specific combining ability in relation to diallel crossing systems. Aust J Biol Sci 9, 463-493.

Hodge, G. R., P. W. Volker and B. M. Potts (1996): A comparison of genetic information from open-pollinated and control-pollinated progeny tests in two eucalypt species. Theor Appl Genet 92, 53-63.

Holland, J. B. (2001): Epistasis and plant breeding. In: Plant breeding reviews, JANICK, J. (editor), 21.
HussendoRFER, E. (1999): Genetic variation of silver fir populations (Abies alba Mill.) in Switzerland. Forest Genetics 6, 2, 101-113.

IsIK, F., B. Li and J. FRAMPTON (2003): Estimates of additive, dominance, and epistatic genetic variances from a clonally replicated test of loblolly pine. Forest Sci 49, 1, 77-88.

Johnson, G. R. and J. N. KING (1998): Analysis of halfdiallel mating designs I: a practical analysis procedure for ANOVA approximation. Silvae Genet 47, 74-79.

KANG, K. S., D. LindGRen and T. J. Mullin (2001): Prediction of genetic gain and gene diversity in seed orchard crops under alternative management strategies. Theor Appl Genet 103, 1099-1107.

KING, J. N., M. J. CARSON and G. R. Johnson (1998): Analysis of disconnected diallel mating designs II: results from a third-generation progeny test of the New Zealand radiata pine improvement programme. Silvae Genet 47, 2-3, 80-88.

KLEIN, J. I. (1998): A plan for advanced-generation breeding of jack pine. Forest Genetics 5, 2, 73-83.

Konnert, M. and F. BERGMAnN (1995): The geographical distribution of genetic variation of silver fir in relation to its migration history. Plant Syst Evol 196, 19-30.

KorPel, S., L. PAUle and A. LAFFERs (1982): Genetics and breeding of the silver fir (Abies alba Mill). Annales Forestales 9/5, 151-184.

KRANENBORG, K. G. (1994): Abies alba provenance research in the Netherlands. 7 IUFRO-Tannensymposium, Deutschland, 369-381.

Kriebel, H. B., G. NAmkoong and R. A. Usanis (1972): Analysis of genetic variation in 1-, 2-, and 3-year-old eastern white pine in incomplete diallel cross experiments. Silvae Genet 21, 1-2, 44-47.

KRIEBEL, H. B., J. H. Roberts and R. V. Cox (1974): Genetic variation in vigour in a white pine incomplete diallel cross experiment at age 6. Northern Research Station. USDA Forest Service.

LARSEN, J. B. and F. MEKIC (1991): The geographic variation in European silver fir. Silvae Genet 40, 5-6, 188-197.

LI, B. and G. W. WyckofF (1994): Breeding strategies for Larix decidua, Larix leptolepis, and their hybrids in the United States. Forest Genetics 1, 2, 65-72.

Olsson, T., D. LindGRen and B. Li (2001): Balancing genetic gain and relatedness in seed orchards. Silvae Genet 50, 5-6, 222-227.

Longauer, R., D. Gomory, S. Liepelt and B. Ziegenhagen (2005): Genetic diversity of Abies alba in the Carpathians and the adjacent regions. In: Proceedings of the $11^{\text {th }}$ International Silver Fir Symposium, Poiana Brasov, Romania, 32.

Matheson, A. C., D. J. Spencer and D. Magnussen (1994): Optimum age for selection in Pinus radiata using basal area under bark for age-age correlations. Silvae Genet 43, 352-357.

MiHAI, G. (2007): An advanced-generation seed orchard for silver fir. Analele ICAS 50, 45-55.

Mihai, G., E. Stuparu, V. Scarlatescu and H. Vlasin (2007): Genetic variation and breeding of silver fir in Romania. Analele ICAS 50, 27-44.

MinAI, G. (editor) (2009): Surse de seminţe testate pentru principalele specii de arbori forestieri din România. Editura Silvică, București, ISBN 978-973-88938-6-3, 280 . 
Morgenstern, E. K. (1974): A diallel cross in black spruce, Picea mariana (Mill.) BSP. Silvae Genet 23, $1-3,67-71$.

Mullin, T. J. and Y. S. PARK (1992): Estimating genetic gains from alternative breeding strategies for clonal forestry. Can J For Res 22, 1, 14-23.

Namkoong, G., E. B. Snyder and R. W. Stonecypher (1966): Heritability and gain concepts for evaluating breeding systems such as seedling orchards. Silvae Genet 15, 76-84.

NAmkoong, G. and J. H. RoberTs (1974): Choosing mating designs to efficiently estimate genetic variance components for trees. Silvae Genet 23, 1-3, 43-53.

Paul, A. D., G. S. Foster, T. Caldwell and J. McRae (1997): Trends in genetic and environmental parameters for height, diameter, and volume in a multi-location clonal study with loblolly pine. Forest Sci 43, 1, 87-98.

SANDU, I. (2013): Schimbari climatice in Romania si efectele asupra resurselor de apa in agricultura. Conferinta nationala Securitatea alimentara si a resurselor de apa: intre perspective europene si realitati nationale, 27 mai Bucuresti.

Schaffer, H. E. and R. A. UsAnIs (1969): General leastsquares analysis of diallel experiments. A computer programme-DIALL. Genetic Dept. Res. Rept. No. 1 North Carolina State University, Raleigh, N.C., 61.

Schmidtling, R.C., and D. Nelson (1996): Interprovenance crosses in loblolly pine using selected parents. Forest Genetics 3, 53-66.

Skroppa, T. (1996): Diallel crosses in Picea abies II: performance and inbreeding depression of selfed families. Forest Genetics 3, 69-79.

Teodosiu, M. (2009): Evaluating the genetic diversity of silver fir by isozyme gene markers. In: Testing seed sources for the main forest species in Romania, MIHAI, G. (editor), Editura Silvică, Bucureşti, ISBN 978-97388938-6-3, 178-184.
White, T. L., G. R. Hodge and G. L. Powell (1993): An advanced-generation tree-improvement plan for slash pine in the south-eastern United States. Silvae Genet 42, 6, 359-370.

Wilcox, M. D., C. J. A. Shelbourne and A. FirTh (1975): General and specific combining ability in eight selected clones of radiata pine. New Zeal J For Sci 85, 219-222.

Wolf, H. (editor) (1994): Silver fir provenances: recent results related to provenance research of Abies alba Mill. Ecomed-Verlag, Landsberg/Lech, 150.

WRIGHT, J. (1971): Second-generation seed orchards of red and white pines in Michigan. Proceedings of the IUFRO, Section 22 Meeting, Gainesville, Florida, 1-9.

Wu, H. X. and A. C. MAtheson (2000): Analysis of halfdiallel mating design with missing crosses: theory and SAS program for testing and estimating GCA and SCA fixed effects. Silvae Genet 49, 130-137.

Wu, H. X. and A. C. Matheson (2001): Analysis of halfdiallel mating design with missing crosses: theory and SAS program for testing and estimating GCA and SCA variance components. Silvae Genet 50, 265-271.

XIANG, B., B. LI and F. IsIK (2003a): Time trend of genetic parameters in growth traits of Pinus taeda L. Silvae Genet 52, 3-4, 114-121.

XIANG, B., B. LI and S. McKeand (2003b): Genetic gain and selection efficiency of loblolly pine in three geographic regions. Forest Sci 49, 2, 196-208.

YANCHUK, A. D. (1996): General and specific combining ability from disconnected partial diallels of coastal Douglas fir. Silvae Genet 45, 1, 37-45.

YEH, F. C. and J. C. HEAMAN (1987): Estimating genetic parameters of height growth in 7-year-old coastal Douglas fir from disconnected diallels. Forest Sci 33, 946-957. 